\title{
Safety in the administration of injectable medications: Scoping review
}

\author{
Segurança na administração de medicamentos injetáveis: Revisão de escopo \\ Seguridad en la administración de medicamentos inyectables: Revisión del alcance
}

Received: 04/23/2021 | Reviewed: 04/30/2021 | Accept: 05/06/2021 | Published: 05/19/2021

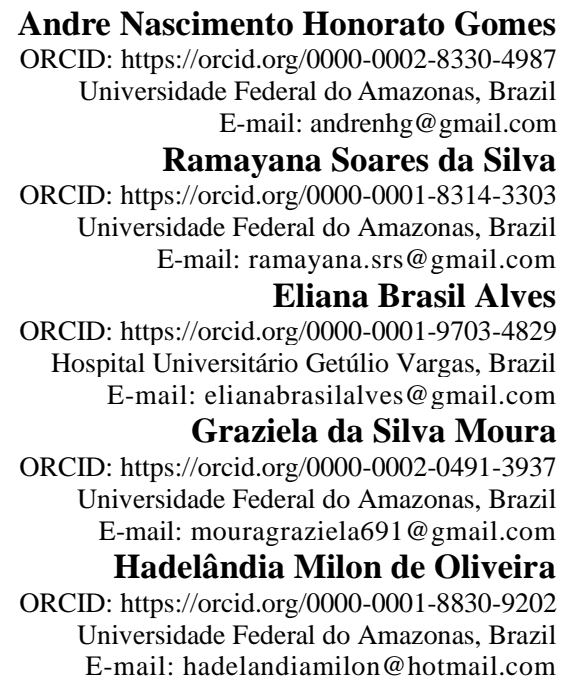

\begin{abstract}
Objective: to raise scientific evidence on technologies for the safe administration of injectable drugs in hospitalized adult patients. Method: this is a study of the Scoping Review type, using the crossing of the descriptors Patient Safety, Medication Errors and Technology in the following databases: Medical Literature Analysis and Retrieval System Online Electronic Library Online, Science Direct, Virtual Health Library, Pubmed, Web of Science and Scopus. The choice of studies included in the sample and data extraction occurred in a paired manner by independent researchers. Results: 14 studies were classified as eligible. The interventions found were medication administration using a barcode, patient identification by plates, bracelets, radiofrequency and/or biometrics, personal digital assistants, mobile nursing carts, electronic medication administration record, safety syringe system based on key-lock adapters, smart infusion pumps, drugs organizer kits, storage bag, trays with dividers, adhesive in different colors for separating medicines by class, and double checking. Final considerations: The implementation of technologies, professionalism, changes in the organization and in the workplace linked to the empowerment of the patient and family/companion enables the quality of the injectable medication administration processes. It is considered an advantageous investment in technologies for the culture of safety.
\end{abstract}

Keywords: Patient safety; Risk management; Medication errors; Medication systems, hospital; Technology; Clinical Protocols.

\section{Resumo}

Objetivo: levantar evidências científicas acerca de tecnologias para a administração segura dos medicamentos injetáveis em pacientes adultos hospitalizados. Método: trata-se de um estudo do tipo Scoping Review, utilizando o cruzamento dos descritores Patient Safety, Medication Errors e Technology nas seguintes bases de dados: Medical Literature Analysis and Retrieval System Online Eletronic Library Online, Science Direct, Biblioteca Virtual de Saúde, Pubmed, Web of Science e Scopus. A escolha dos estudos incluídos na amostra e extração dos dados ocorreu de forma pareada por pesquisadores independentes. Resultados: 14 estudos foram classificados como elegíveis. As intervenções encontradas foram: administração de medicamentos com código de barras, identificação do paciente por placas, pulseiras, radiofrequência e/ou biometria, assistentes pessoais digitais, carrinhos móveis de enfermagem, registro eletrônico de administração de medicamentos, sistema de seringas de segurança baseado em adaptadores chave-fechadura, bombas de infusão inteligentes, kits organizadores de medicamentos, sacola para armazenamento, bandejas com divisórias, adesivo com diferentes cores para separação dos medicamentos por classe, e dupla checagem. Considerações finais: a implementação de tecnologias, profissionalismo, mudanças na organização e no ambiente de trabalho atrelados ao empoderamento do paciente e familiar/acompanhante possibilitam a qualidade dos 
processos de administração de medicamentos injetáveis. Considera-se vantajoso o investimento em tecnologias voltadas para a cultura de segurança.

Palavras-chave: Segurança do paciente; Gestão de riscos; Erros de medicação; Sistema de medicação no hospital; Tecnologia; Protocolos clínicos.

\section{Resumen}

Objetivo: recabar evidencia científica sobre tecnologías para la administración segura de medicamentos inyectables en pacientes adultos hospitalizados. Método: se trata de un estudio de revisión de alcance, utilizando el cruce de los descriptores Seguridad del paciente, Errores de medicación y Tecnología en las siguientes bases de datos: Medical Literature Analysis and Retrieval System Online Electronic, Library Online, Science Direct, Biblioteca Virtual en Salud, Pubmed, Web of Science y Scopus. La elección de los estudios incluidos en la muestra y la extracción de datos se produjo de forma pareada por investigadores independientes. Resultados: 14 estudios se clasificaron como elegibles. Las intervenciones encontradas fueron: administración de medicamentos con código de barras, identificación del paciente mediante placas, brazaletes, radiofrecuencia y/o biometría, asistentes digitales personales, carros de enfermería móviles, registro electrónico de administración de medicamentos, sistema de jeringa de seguridad basado en adaptadores con llave, bombas de infusión inteligentes, botiquines organizadores de medicamentos, bolsa de almacenamiento, bandejas con separadores, adhesivo de diferentes colores para separar los medicamentos por clases y doble control. Consideraciones finales: la implementación de tecnologías, la profesionalidad, los cambios en la organización y en el ambiente laboral ligados al empoderamiento del paciente y su familia/acompañante posibilitan la calidad de los procesos de administración de medicamentos inyectables. Se considera ventajosa la inversión en tecnologías orientadas a la cultura de la seguridad.
\end{abstract}

Palabras clave: Seguridad del paciente; Gestión de riesgos; Errores de medicación; Sistema de medicación em hospital; Tecnología; Protocolos clínicos.

\title{
1. Introduction
}

The subject of patient safety became relevant in health debates with the publication of the report "To Err is Human: Building a Safer Health System" from the United States Institute of Medicine, in 1999. The proposal of the text brought alarming numbers showing that adverse events, those arising from health care and not from the underlying disease, generated more deaths than diseases such as AIDS, breast cancer, and traffic-accidents, in addition to causing serious financial expenses (Brazil, 2014).

Adverse events related to the medication process are among those that most affect hospitalized individuals. To take medication to a patient in this environment, several steps are taken, from medical prescription, dispensing by the pharmacy, and administering the medication to the patient. Failures and complications can occur at any time and may have serious consequences for the patient, institution, and health care professionals (Brazil, 2013).

Administration errors are defined as any deviation in the preparation and administration of medications that differ from the therapy planned by the health care team, the medication package leaflet, or institutional recommendations (Gimenes, 2016). Therefore, it should be emphasized that one of the six International Patient Safety Goals, established by the World Health Organization (WHO) and recommended by the Joint Commission International, is to improve safety in the prescription, use, and administration of medicines (Franciscatto, Bessow, Ruzczyk, Oliveira \& Kluck, 2012).

Overall, errors involving medications can occur in several steps, with $49 \%$ resulting from incorrect prescriptions and $26 \%$ of incidents occurring during administration. In the case of Brazil, there are not enough studies to accurately portray the scenario of medication administration. However, most research shows that the main misconceptions occur in the dosage and timing of medications (Gimenes, 2016). It is noteworthy that in the medication administration process, the patient or family member/companion, when well oriented and empowered, constitutes the last step/barrier to prevent the occurrence of errors (Ramos, Pina, Neves, Moura \& Oliveira, 2020).

In mid-2017, the WHO launched a focused challenge for the administration of drugs without damage, proposing that maladministration has a reduced rate of $50 \%$ in serious and avoidable harm. From this perspective, the challenge focuses on 
advances in systems and medication practices, showing the egregious contact and understanding of broad technologies which help to prevent errors in medication, and also mitigating the costs arising from such errors (OPAS, 2017).

In healthcare practice, there is a need to standardize/update protocols and guidelines for drug administration. This will make it possible to intervene by reducing the risks and unnecessary damages that are associated with health care, thus contributing to an advance in one of the International Goals of Patient Safety and impacting on the improvement of the quality of health care. For this purpose, this study aimed to raise scientific evidence on technologies for the safe administration of injectable drugs in hospitalized adult patients.

\section{Methodology}

This is Scoping Review study which is a variation of systematic literature review that makes it possible to search for theoretical framework and understanding about the theme in different databases, being a consistent methodology for evidencebased practice (Peterson, Pearce, Ferguson \& Langford, 2017). The protocol recommended by the Joanna Briggs Institute Reviewer's Manual (JBI) and the flowchart of the Preferred Reporting Items for Systematic Reviews and Meta-Analyzes Extension for Scoping Review (PRISMA-ScR) were followed, which details the process of selecting the collected data (Peters, Godfrey, McInerney, Munn, Tricco \& Khalil, 2020). Six stages were established for the development of this scoping review, namely:

Stage 1: Definition of the research question. Due to the interest in the creation and validation of an Assistance Protocol, focused on Patient Safety, it was decided to "safe administration of injectable drugs in hospitalized adults" as the selected theme and "What are the technologies recommendations in the scientific literature for the elaboration of a protocol for safe administration of injectable drugs to hospitalized adults?" as the guiding question of this study.

Stage 2: Definition of the relevant studies for the research. The controlled terms were defined from the Descriptors in Health Sciences (DeCS), performing the crossing through the boolean logical operator AND. The following terms were used: Patient Safety, Medication Errors and Technology. The databases defined for the search were: Medical Literature Analysis and Retrieval System Online Electronic Library Online (SciELO), Science Direct, Biblioteca Virtual de Saúde (BVS), Pubmed, Web of Science e Scopus. It was decided to include in this research: original articles fully available in electronic format, in English, Spanish or Portuguese, with time restriction from 2015 to 2019. The established exclusion criteria were articles that were not available in full in the researched databases and those related to the animal model. Publications that did not address the theme of this study, involving outpatient settings, and those that presented safe administration of injectable medications in children or neonates were disregarded.

Stage 3: Selection of studies. The choice of studies included in the sample and data extraction occurred in a paired manner by independent researchers, from the verification of duplicate publications, reading the title, reading the abstract, and, finally, reading the entire text. The guidelines of the PRISMA-ScR (Preferred Reporting Items for Systematic Reviews and MetaAnalyzes Extension for Scoping Review) were followed to systematize the process of inclusion of the studies (Moher, Liberati, Tetzlaff \& Altman, 2009).

Stage 4: Mapping of selected data for research. A table was created in the Microsoft Office program in order to organize the content of the publications and facilitate the analysis and discussion of the results found.

Stage 5: Collection, synthesis, and description of data. At this stage, the implications of the study's results for care practice were identified. The description of the data was presented in a thematic way and systematization was important to avoid bias, in addition to making the review reproducible. 
Stage 6: Assessment of the quality of evidence according to the GRADE System - Grading of Recommendations Assessment, Development, and Evaluation (Brazil, 2014).

\section{Results}

The search strategy used in the databases found 1314 articles. Of these, 1188 articles were excluded as inclusion criteria were applied, totaling 126 articles in the identification stage. After the elimination of 17 duplicates, 109 studies were obtained for the selection phase. The titles and abstracts were screened and analyzed, in a paired way, in order to exclude the irrelevant ones. It was filtered to 53 studies to be analyzed in the next step. Finally, after reading the articles in full, 39 articles were excluded because they did not present significant contributions to this study. As a course, only 14 studies were classified as eligible and included in this review.

In order to clarify the search, exclusion and selection process of the studies that comprised the sample of this research, a flowchart (Figure 1) was elaborated, following the recommendations of the Joanna Briggs Institute, according to the checklist adapted from the PRISMA-ScR (JBI, 2015).

Figure 1. PRISMA flowchart for the study search, exclusion, and selection.

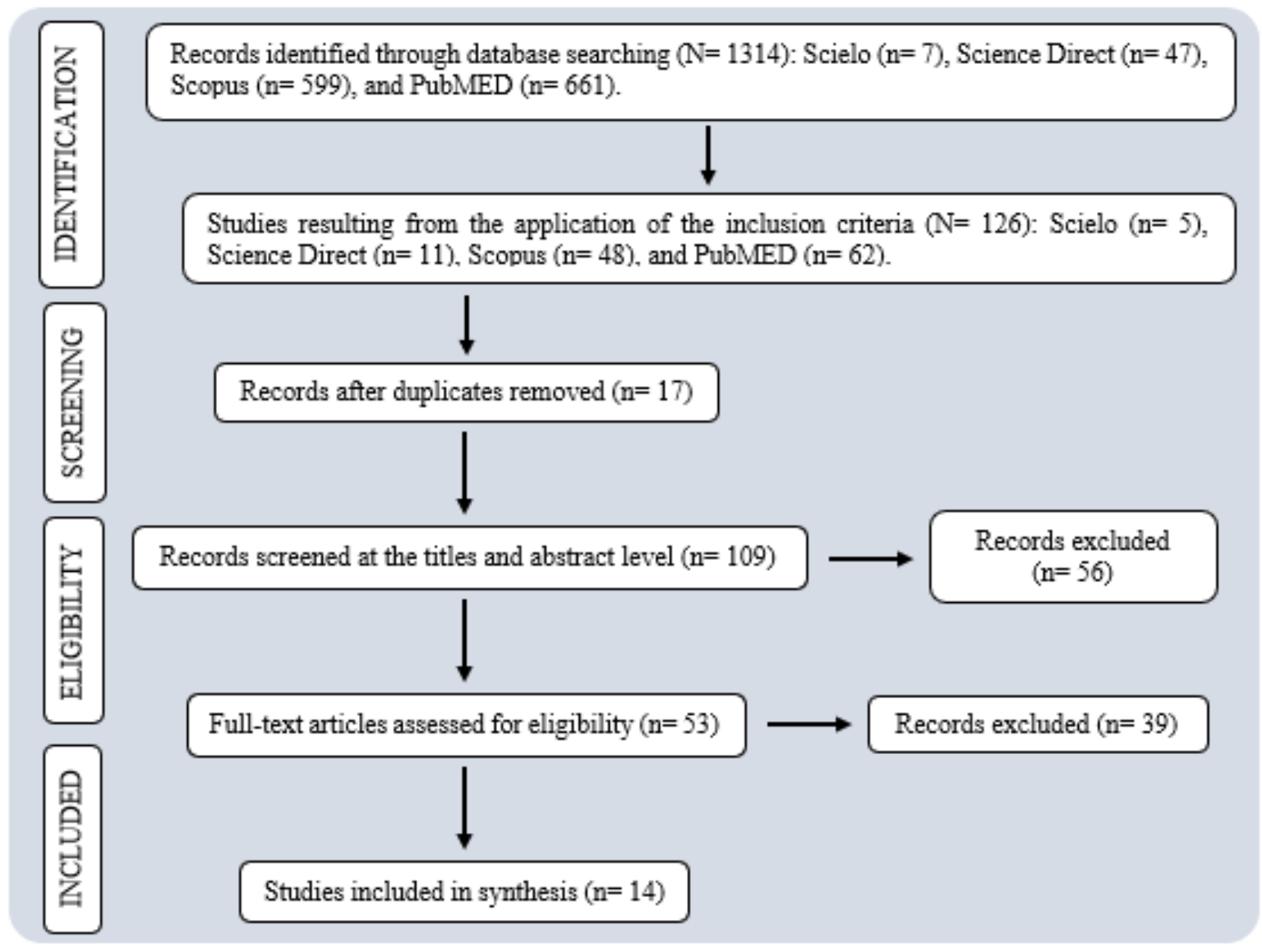

Model adapted from the PRISMA flowchart. Source: Authors (2020).

The reasons for exclusion during the selection process were studies focusing only on prescription and/or medication dispensing; pediatrics; non-hospital environments; ongoing studies; and those who did not address the proposed theme.

Among the 14 eligible articles, the majority are of international origin, with only two held in Brazil. Regarding the date of publication, the largest quantity refers to the year 2017. The qualitative approach was the most used method. 
Table 1 characterize data from the studies found. Its composition was based on the following variables investigated in the publications: authors, year of publication, country of origin of the study, objective, and methodological design. In addition, the result of the evaluation of the quality of evidence evaluated by the GRADE system was included.

Table 1. Characterization of the studies included in the review.

\begin{tabular}{|c|c|c|c|}
\hline Authors & Year & Origin & Objective \\
\hline $\begin{array}{c}\text { Magalhães, Moura, } \\
\text { Pasin, Funcke, Pardal \& } \\
\text { Kreling }\end{array}$ & 2015 & Brazil & $\begin{array}{l}\text { To conduct a survey of critical points in the } \\
\text { medication process, its repercussions on the } \\
\text { demands made on the nursing team and risks } \\
\text { related to patient safety. }\end{array}$ \\
\hline $\begin{array}{c}\text { Orbæk, Gaard, } \\
\text { Fabricius, Lefevre \& } \\
\text { Møller }\end{array}$ & 2015 & Denmark & $\begin{array}{l}\text { To explore nursing students' experiences and } \\
\text { competences with the technology-driven } \\
\text { medication administration process. }\end{array}$ \\
\hline Uy, Kury \& Fontelo & 2015 & $\begin{array}{c}\text { United States } \\
\text { of America }\end{array}$ & $\begin{array}{l}\text { To determine the state and trends of adoption } \\
\text { of these technologies in *U.S. hospitals. }\end{array}$ \\
\hline $\begin{array}{l}\text { Wang, Jin, Feng, Huang, } \\
\text { Zhu, Zhao \& Zhou }\end{array}$ & 2015 & China & $\begin{array}{l}\text { To discuss the effectiveness of such } \\
\text { stewardship intervention in inpatient care and } \\
\text { provide some reference for international } \\
\text { counterparts. }\end{array}$ \\
\hline $\begin{array}{l}\text { Shah, Lo, Babich, Tsao } \\
\text { \& Bansback }\end{array}$ & 2016 & Canada & $\begin{array}{c}\text { To determine the impact of }{ }^{\dagger} \mathrm{BCMA} \text { on } \\
\text { medication errors when used as part of a } \\
\text { closed-loop medication administration system. }\end{array}$ \\
\hline $\begin{array}{l}\text { Franz, Robertson, Spiro, } \\
\text { Ramirez, McEvoy, } \\
\text { Thompson, Clayman, } \\
\text { Graeff, Mankad, Baird, } \\
\text { Suko, Galati, Recchiuti, } \\
\text { Gatsos-Walter, } \\
\text { Benjamin, Ebert, } \\
\text { Callinan \& Henderson }\end{array}$ & 2016 & $\begin{array}{l}\text { United States } \\
\text { of America }\end{array}$ & $\begin{array}{l}\text { To provide best practices and guidance for } \\
\text { improved electronic detection and alerting of } \\
\text { inadvertent supratherapeutic cumulative doses } \\
\text { of acetaminophen and other medications with } \\
\text { narrow therapeutic ranges in inpatient settings. }\end{array}$ \\
\hline Alotaibi \& Federico & 2017 & $\begin{array}{l}\text { Kingdom of } \\
\text { Saudi Arabia }\end{array}$ & $\begin{array}{l}\text { To summarize the current available scientific } \\
\text { evidence on the impact of different health } \\
\text { information technologies on improving patient } \\
\text { safety outcomes. }\end{array}$ \\
\hline Risør, Lisby \& Sørensen & 2017 & Denmark & $\begin{array}{l}\text { Economic evaluation and study of } \\
\text { effectiveness before and after controlled. }\end{array}$ \\
\hline $\begin{array}{l}\text { Debono, Taylor, } \\
\text { Lipworth, Greenfield, } \\
\text { Travaglia, Black \& } \\
\text { Braithwaite }\end{array}$ & 2017 & Australia & $\begin{array}{l}\text { To identify barriers and targeted interventions } \\
\text { to enhance nurses' appropriate use of 'EMMS } \\
\text { in two Australian hospitals. }\end{array}$ \\
\hline Cho, Lee, Cho \& Choy & 2017 & $\begin{array}{l}\text { Coreia } \\
\text { do Sul }\end{array}$ & $\begin{array}{l}\text { To suggest a safety injection system that can } \\
\text { physically prevent the connection of a syringe } \\
\text { tip to a catheter injection-port when there is a } \\
\text { mismatch between a drug and patient or route. }\end{array}$ \\
\hline
\end{tabular}

Retrospective descriptive Analysis (Quantitative)

Intervention study

(Experimental)

Systematic Review

Moderate

White paper

Moderate

Systematic Review

Moderate

Economic evaluation and controlled before-andafter effectiveness study

Low

$$
\begin{gathered}
\text { Theoretical Domain } \\
\text { Structure } \\
\text { (Qualitative) }
\end{gathered}
$$

Design and development (Experimental)

Low 
Shola \& Neela

Narayanan

India

Thompson, Swanson, Cox, Kirchner, Russel, Wermers, Storlie, Johnson \& Naessens United States of America

Vilela \& Jericó 2019

Brazil

Burkoski, Yoon, Solomon, Hall, Karas, Jarrett \& Collins
To survey on ${ }^{\circledR}$ PCA pump errors, adverse events, and solutions for it to avoid them.

Literature review

Low

To evaluate the impact of implementing the BCMA technology on the rate of medication administration errors in the inpatient practice, with a specific focus on errors that resulted in patient harm.

To calculate the cost and assess the results on implementing technological resources that can prevent medication errors.

To evaluate the effects of barcode medication administration and the closed-loop medication system interventions on medication errors and adverse drug event rates.
(Experimental and observational)

Low

Retrospective, descriptive-exploratory, Low quantitative

$$
\begin{aligned}
& \text { Quasi-experimental } \\
& \text { design }
\end{aligned}
$$

Intervention study

"US= United States of America; ${ }^{\dagger} \mathrm{BCMA}=$ Bar Code Medication Administration; ${ }^{\ddagger} \mathrm{EMMS}=$ Electronic Medication Management Systems; ${ }^{\S} \mathrm{PCA}=$ Patient-controlled analgesia.

Source: Authors (2020).

Figure 2 shows the interventions found for the safe administration of injectable drugs. It is noteworthy that the medication process occurs interdependently, therefore improvements must be made in the steps and sub-steps of prescription, dispensing, and administration of medications in order to achieve satisfactory results for patient safety. Furthermore, studies have shown that it is advantageous to invest in technologies focused on the safety culture.

Figure 2. Interventions and strategies for safe patient identification and safe administration of medications.

\begin{tabular}{|l|l|}
\hline \multicolumn{1}{|c|}{ SAFE IDENTIFICATION OF PATIENT } & SAFE ADMINISTRATION OF MEDICATIONS \\
\hline Identification of the patient by radiofrequency & Plastic bag for medicine \\
Identification of the patient by biometrics & Trays with dividers \\
Patient identification plate & Mobile nursing carts \\
Patient identification bracelet & Adhesive with different colors for drug separation by \\
class \\
Electronic Medication Management Systems & Drug's organizer kits in the operating room \\
Double check & Security syringe system based on key-lock adapters \\
Personal digital assistants & Computerized infusion pumps with wireless \\
& connectivity and medication library \\
& Intelligent infusion pumps \\
& Guidelines and Trainings \\
& Organization in the work shift \\
& Scales for measuring nursing workload \\
& Adequate staff allocation \\
& Support of the hospital structure and organization \\
\hline
\end{tabular}

Weak Recommendation

Strong Recommendation

Source: Authors (2020) 
The studies included management interventions that contributed to patient safety in this process, such as training, guidelines, the organization in the work shift, scales for measuring the nursing workload, allocation of adequate staff, and support of the hospital structure and organization.

The most frequent errors related to the medication process were incorrect medication, incorrect medication form, incorrect route, incorrect dose, advance or delay in medication administration, incorrect patient, incorrect note, and drug interaction. Furthermore, it is emphasized that the lack of guidance to the patient on the received medication therapy may also be considered a failure of the process.

\section{Discussion}

The provision of measures aimed at reducing errors must come with interventions based on specific points: professionalism, work environment, and safety culture (Figure 3). The first is related to the need for frequent training and updates for health professionals, the provision of adequate staff and professional workload, in addition to the need for improvements in interpersonal communication. The second reinforces the idea that the environment has an influence on actions and thus in health care, requiring environmental control, providing the necessary equipment and supplies in sufficient quantities, and seek to implement the new technologies for the development of safe activities. And, finally, the safety culture, which must be understood and practiced by all sectors of the health unit, since it is essential to improve the clinical status of the patient and protect the workers involved in this process (Wang et al., 2015).

Figure 3. Fundamentals for patient safety.

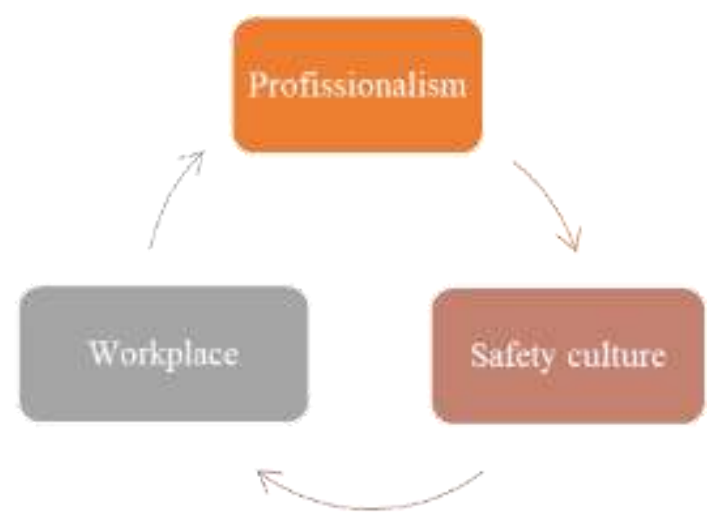

Source: Authors (2020).

The association between the workload of the nursing team and patient safety was one of the topics identified in the studies. It is observed that the increase in the occurrence of adverse events is causally related to the work overload of the team. Among the numerous activities performed, it is emphasized that the medication process requires time and increased attention, since the iatrogenic events resulting from it can be fatal (Magalhães et al., 2015). It is necessary an effective articulation between the stages of this process, in which the implementation and use of new technologies demonstrated favorable results in the prevention of medication errors, as they reduced the overload of the professionals' activities and allowed an increase in the surveillance and guidance of the nursing team with hospitalized individuals, favoring patient safety.

Orbæk et al. (2015) highlight the importance of training since professional qualification, considering that it in the care practice environment that academics acquire better assimilation of theoretical knowledge and become familiar with existing hospital technologies. Nursing science has a broad performance in the development of its technical and scientific 
skills, including the safe administration of medicines. Therefore, acting in the development of drug administration processes, still in undergraduate studies, is fundamental to minimize errors resulting from failures during professional activities.

The creation and supply of technologies are increasing in order to improve working conditions and health care safety. It is observed that these innovations present varied conformations and purposes, besides having the ability to be used in an articulated way, thriving with the safety culture. The studies presented showed that the use of certain interventions during the drugs administration process avoids or confirms the significant reduction of the iatrogenic complications resulting from this process.

The implementation of the barcode system within health services has gained prominence in recent years, especially among world-leading hospitals. This is due to the fact that it has applicability in all sectors and various functions, besides adding a significant reduction in errors arising from professional assistance (Shah et al., 2016). It is worth noting that this technology obtained even more satisfactory results when performed in a closed-circuit medication system (CLMS), that is, containing electronic registration of electronic medication administration (eMAR) plus the computerized entry of prescribers' orders (CPOE); automatic dispensing device (ADD), bar code medication administration system (BCMA) and the use of smart infusion pumps. There are studies that further improve the CLMS with the clinical decision support system (CDS), which uses artificial intelligence as a contributor to health care (Burkoski et al., 2019).

Uy et al. (2015) provide important information for carrying out strategic planning and implantation of technologies that aim at patient safety and are being widely used by hospitals around the world. Their study made a comparison between the use of four systems: BCMA, radiofrequency identification (RFID), biometrics (fingerprints and iris) and pharmacy automation. These technologies were widespread among the sectors evaluated and demonstrate the importance of the association between information technology and health care, especially in the medication process. However, when evaluating the process of adoption of these interventions, it was noticed that BCMA and pharmacy automation had the highest rates of use, while RFID and biometrics had low technological adherence, with costs and perceptions as the main barriers to implementation.

The inclusion of technologies in health facilities function as fundamental safety mechanisms, favoring the reduction and even absence of inaccuracy in the application of drugs in a hospital environment. Thus, it is intuitive that the investment in technologies is real and based on scientific evidence of quality, seeking to identify and analyze its effectiveness when referring to the indicator of quality, frequency, and incidence of errors in drug administration.

Vilela et al. (2019) evaluated the cost and effectiveness of the implementation of technologies aimed at the administration of medication. The investments made in the study comprise values of approximately $R \$ 3,251,757.00$ in prescription technologies, approximately $R \$ 2,979,397.10$ in the dispensation, and the amount of $R \$ 4,028,351.00$ in the administration, considering the current minimum wage of $\mathrm{R} \$ 722.00$ and $\mathrm{R} \$ 788.00$ in the years of acquisition of the technologies, i.e., 2014 and 2015, respectively. It is also stated that the indicator of incidence of medication error decreased by 97.5\%, gradually, between 2007 and 2015, that is, before, during, and after the implementation of the technologies.

In relation to another statistical demonstration, the study by Thompson et al. (2018) in a large academic hospital center recognized in the United States of America demonstrated that the implementation of BCMA showed a significant decrease in $43.5 \%$ of medication-related errors. For this, the technology was added to the computerized medical prescription entry system, verification by pharmacists, and electronic drug administration records with allergy recognition and drug interaction. Besides, there was an articulation between education and communication activities and management towards the team, aiming at increasing the rate of adherence to the use of technology and optimizing the nursing workflow. It is emphasized that this technology allowed the direct communication of errors and near misses, which contributes to the statistical evaluation of the hospital and guides possible preventive actions. 
Wang et al. (2015) portrayed the use of a series of interventions during the journey to the accreditation of a hospital in China. From the development of systems and the implementation of technologies in conjunction with the training of the multidisciplinary team, it was possible to reduce errors related to medication administration. Therefore, it is noted that the search for institutional recognition contributes to the improvement of health care since there is a need for the implementation of resources. It is worth mentioning that large investments in information technology equipment are necessary when looking for improvements, following the logic of health systems around the world, it becomes more economically advantageous to invest in prevention than to act after the emergence of problems.

The study by Cho et al. (2017) presents a differentiated alternative compared to other studies. It is about the creation of a safety injection system in the key-lock style, in which there are two different adapters (one in the syringe and the other in the catheter), which allow injection errors to be avoided and interrupted at the source, that is when the drug and the route or the patient are incompatible. It is necessary 3D printing machinery and an estimated time of 3.5 hours for the production of your parts. In addition, the authors report that there is the possibility of creating thousands of different combinations to adapt the system according to the medications and/or classes of drugs to be used, making it a study with great potential in patient safety. However, to confirm this information, it is necessary to carry out experimental studies, such as clinical trials, to analyze and prove its usability within the health care routine.

Regarding the use of infusion pump, this was described as one of the essential interventions for the administration of medications in the studies by Franz et al. (2016), Alotaibi et al. (2017), and Vilela et al. (2019), since they reduced errors related to the dosage. It is note point that modernity also brings the improvement of health equipment to make them even more effective and easy to use. Therefore, there are intelligent computerized infusion pumps with wireless connectivity and a medication library, which have a direct connection to the electronic health systems and can be controlled directly according to the prescription made (Shola et al., 2017). It is important to mention that these technologies must be updated frequently according to the insertion/exclusion of drugs available on the market, as well as the recommended dosage limits recommended. In addition, there is a need to train professionals who will use them to maximize their functionality.

\section{Final Considerations}

Returning to the research question of what the recommendations of the scientific literature for the safe administration of injectable medications in hospitalized adults are, it was listed that the investment and implementation of technologies focused on the safety culture, linked to professionalism and changes in the organization and work environment allow the reduction of errors related to the medication process.

It is emphasized that the search for improvements related to patient safety requires adequate financial, material, and professional resources. The imbalance between at least one of these factors may not bring about the effectiveness of the implemented technologies and, consequently, an index that is not expected. Therefore, in addition to achieving the best results, it is necessary to plan all the actions involved in this process, the constant training of the teams and the realization of the necessary updates in each implemented system.

Every professional involved in the process of safe administration of injectable drugs should be aware of their role in reducing adverse events, which involves meeting the measures recommended by the Ministry of Health, institutional protocols combined with the introduction of technologies that will impact the reduction of adverse events. Given this, the nursing team is highlighted, which has an important and essential role in the preparation and administration of medications, as well as in monitoring the desired organic response and the occurrence of adverse effects.

It is also ensured that the measures do not cause completely efficient protection, but it is understood that they constitute a protective barrier for the patient, since medication errors can be preventable. 
The lack of studies involving technical and scientific issues related to the administration and infusion of injectable drugs under other aspects, such as preparation actions, use of diluents, the dilution and flow process, infusion speed, was configured as the main limitation of this study. In addition, most of the evidence found shows a very low degree of reliability due to the methodologies of studies conducted and the possible presence of biases. It is necessary to carry out well-designed studies related to the administration of injectable drugs, as it is a process that requires greater complexity.

\section{References}

Alotaibi, Y. K., \& Federico, F. (2017). The impact of health information technology on patient safety. Saudi Medical Journal, 38(12), 1173-1180. https://doi.org/10.15537/smj.2017.12.20631

Brazil. (2013). Protocolo de Segurança na Prescrição, Uso e Administração de Medicamentos. Protocolo coordenado pelo Ministério da Saúde e ANVISA em parceria com FIOCRUZ e FHEMI. https://portalarquivos2.saude.gov.br/images/pdf/2014/julho/03/Protocolo-Medicamentos.pdf

Brazil. (2014). Documento de referência para o Programa Nacional de Segurança do Paciente. http://bvsms.saude.gov.br/bvs/publicaco es/documento_referencia_programa_nacional_seguranca.pdf

Brazil. (2014). Diretrizes metodológicas: Sistema GRADE - Manual de graduação da qualidade da evidência e força de recomendação para tomada de decisão em saúde. http://bvsms.saude.gov.br/bvs/publicacoes/diretrizes_metodologicas_sistema_grade.pdf

Burkoski, V., Yoon, J., Solomon, S., Hall, T. N. T., Karas, A. B., Jarrett, S. R., \& Collins, B. E. (2019a). Closed-Loop Medication System: Leveraging Technology to Elevate Safety. Nursing Leadership (Toronto, Ont.), 32, 16-28. https://doi.org/10.12927/cjnl.2019.25817

Cho, Y. C., Lee, S. H., Cho, Y. H., \& Choy, Y. B. (2017). Adapter-based Safety Injection System for Prevention of Wrong Route and Wrong Patient Medication Errors. Journal of Korean Medical Science, 32(12), 1938-1946. https://doi.org/10.3346/jkms.2017.32.12.1938

Debono, D., Taylor, N., Lipworth, W., Greenfield, D., Travaglia, J., Black, D., \& Braithwaite, J. (2017). Applying the Theore tical Domains Framework to identify barriers and targeted interventions to enhance nurses' use of electronic medication management systems in two Australian hospitals. Implementation Science, volume 12(1), 42. https://doi.org/10.1186/s13012-017-0572-1

Franciscatto, L., Bessow, C., Ruzczyk, J., Oliveira, M., \& Kluck, M. (2012). Metas internacionais de segurança do paciente em hospital universitário. Clinical \& Biomedical Research, volume 31(4), 482-486. https://seer.ufrgs.br/hcpa/article/view/21146/14967

Franz, R., Robertson, S., Spiro, S., Ramirez, D., McEvoy, G., Thompson, S., Clayman, A. E., Graeff, C. C., Mankad, H., Baird, J., Suko, J., Galati, K., Recchiuti, K., Gatsos-Walter, J. A., Benjamin, P., Ebert, R., Callinan, S., \& Henderson, T. (2016). NCPDP recommendations for dose accumulation monitoring in the inpatient setting: Acetaminophen case model, version 1.0. American Journal of Health-System Pharmacy, 73(15), 1144-1165. http://doi.org/10.2146/ajhp160215

Gimenes, F. (2016). Administração: Não basta usar, é preciso conhecer a maneira correta. In: Uso Racional de Medicamentos: fundamentação em condutas terapêuticas e nos macroprocessos da Assistência Farmacêutica. Brasília: OPAS/OMS

JBI (Joanna Briggs Institute). (2015) Methodology for JBI Scoping Reviews -Joanna Briggs $2015 . \quad$ Australia: JBI; c2015. https://nursing.lsuhsc.edu/JBI/docs/ReviewersManuals/Scoping.pdf

Magalhães, A. M. M. de, Moura, G. M. S. S. de, Pasin, S. S., Funcke, L. B., Pardal, B. M., \& Kreling, A. (2015). Processos de medicação, carga de trabalho e a segurança do paciente em unidades de internação. Rev. Esc. Enferm. USP, 49, 43-50. https://doi.org/10.1590/S0080-623420150000700007

Moher, D., Liberati, A., Tetzlaff, J., Altman, D. G. (2009). Preferred Reporting Items for Systematic Reviews and Meta Analyses: The PRISMA Statement. PLoS Medicine, volume 6(7), e1000097. http://doi.org/10.1016/j.jclinepi.2009.06.005

OPAS (Organização Panamericana de Saúde). (2017). OMS lança esforço global para reduzir pela metade os erros relacionados à medicação em cinco anos. https://www.paho.org/bra/index.php?option=com_content\&view=article\&id=5384:oms-lanca-esforco-global-para-reduzir-pela-metade-os-erros-relacionadosa-medicacao-em-cinco-anos \&Itemid=838

Orbæk, J., Gaard, M., Fabricius, P., Lefevre, R. S., \& Møller, T. (2015). Patient safety and technology-driven medication-A qualitative study on how graduate nursing students navigate through complex medication administration. Nurse Educ Pract, 15(3), 203-211. https://doi.org/10.1016/j.nepr.2014.11.015

Peters, M. D. J., Godfrey C., McInerney P., Munn Z., Tricco A. C. \& Khalil H. (2020). JBI Manual for Evidence Synthesis. Chapter11: Scoping Reviews https://doi.org/10.46658/JBIMES-20-12

Peterson, J., Pearce, P. F., Ferguson, L. A., \& Langford, C. A. (2017). Understanding scoping reviews: Definition, purpose, and process. Journal of the American Association of Nurse Practitioners, 29 (1), 12-16. http://doi.org/10.1002/2327-6924.12380

Ramos, R. da S., Pina, R. M. P., Neves, J. C., Moura, G. da S., \& Oliveira, H. M.. (2021). O protagonismo de usuários em um hospital escola no Amazonas: Percepção acerca da segurança do paciente. Research, Society and Development, 10(3), e37510313597. https://doi.org/10.33448/rsd-v10i3.13597

Risør, B. W., Lisby, M., \& Sørensen, J. (2017). Cost-Effectiveness Analysis of an Automated Medication System Implemented in a Danish Hospital Setting. Value in Health: The Journal of the International Society for Pharmacoeconomics and Outcomes Research, 20(7), 886-893. https://doi.org/10.12927/cjnl.2019.25817

Shah, K., Lo, C., Babich, M., Tsao, N. W., \& Bansback, N. J. (2016). Bar code medication administration technology: A systematic review of impact on 
Research, Society and Development, v. 10, n. 6, e1510615381, 2021

(CC BY 4.0) | ISSN 2525-3409 | DOI: http://dx.doi.org/10.33448/rsd-v10i6.15381

patient safety when used with computerized prescriber order entry and automated dispensing devices. Canadian Journal of Hospital Pharmacy, 69 (5), 394 402. https://doi.org/10.12927/cjnl.2019.25817

Shola, U. R., \& Neela Narayanan, V. (2017). A review on patient-controlled analgesia infusion system. Asian Journal of Pharmaceutical and Clinical Research, 10, 117-121. https://doi.org/10.12927/cjnl.2019.25817

Thompson, K. M., Swanson, K. M., Cox, D. L., Kirchner, R. B., Russell, J. J., Wermers, R. A., Storlie, C. B., Johnson, M. G., \& Naessens, J. M. (2018). Implementation of Bar-Code Medication Administration to Reduce Patient Harm. Mayo Clinic Proceedings: Innovations, Quality \& Outcomes, 2 (4), $342-351$. https://doi.org/10.12927/cjn1.2019.25817

Uy, R. C. Y., Kury, F. P., \& Fontelo, P. A. (2015). The State and Trends of Barcode, RFID, Biometric and Pharmacy Automation Technologies in US Hospitals. AMIA Annual Symposium Proceedings, 1242-1251. https://www.researchgate.net/publication/299389487_The_State_and_Trends_of_Barco de_RFID_Biometric_and_Pharmacy_Automation_Technologies_in_US_Hospitals

Vilela, R. P. B., \& Jericó, M. C. (2019). Implementing technologies to prevent medication errors at a high-complexity hospital: Analysis of cost and results. Einstein (São Paulo), 17(4), eGS4621. http://doi.org/10.31744/einstein_journal/2019GS4621

Wang, H. F., Jin, J. F., Feng, X. Q., Huang, X., Zhu, L. L., Zhao, X. Y., \& Zhou, Q. (2015). Quality improvements in decreasing medication administration errors made by nursing staff in an academic medical center hospital: A trend analysis during the journey to Joint Commission International accreditation and in the post-accreditation era. Therapeutics and Clinical Risk Management, 11, 393-406. https://doi.org/10.12927/cjnl.2019.25817 